\title{
PERILAKU PEDAGANG PADI DITINJAU DARI SOSIOLOGI EKONOMI ISLAM DAN ETIKA BISNIS ISLAM
}

\author{
Agus Koni $^{1}$ \\ Wawan Kurniawan ${ }^{2}$ \\ Ade Albayan ${ }^{3}$ \\ Irma Mandasari Hatta ${ }^{4}$ \\ ${ }^{1}$ Ekonomi Syariah, STEI Al-Amar Subang \\ Email : agus.koni@steialamar.ac.id \\ ${ }^{2}$ Ekonomi Syariah, STEI Al-Amar Subang \\ Email : wawan.kurniawan@steialamar.ac.id \\ ${ }^{3}$ Perbankan Syariah, STEI Al-Amar Subang \\ Email : Ade.albayan@steialamar.ac.id \\ ${ }^{4}$ Ekonomi Syariah, STEI Al-Amar Subang \\ Email : irma.mandasarihatta@steialamar.ac.id
}

\begin{abstract}
Abstrak
Penelitian ini bertujuan untuk mengetahui bagaimana kondisi perilaku pedagang beras ditinjau dari Sosiologi Ekonomi Islam dan Etika Bisnis Islam. Tujuan dari penelitian ini adalah untuk dapat memberikan kontribusi pada usaha beras di Desa Karanghegar Kecamatan Pabuaran Kabupaten Subang Provinsi Jawa Barat. Metode yang digunakan dalam penelitian ini adalah metode deskriptif kualitatif. Hasil penelitian menunjukan bahwa perilaku pedagang padi ditinjau dari sosiologi Ekonomi Islam Unsur kecurangan untuk meraup keuntungan yang sebesar-besarnya, terkait dengan sikap kejujuran sangat sulit diterapkan dengan alasan mereka rugi. Perilaku pedagang padi ditinjau dari Etika Bisnis Islam yakni Perilaku pedagang padi dalam transaksi tidak sesui dengan etika bisnis ada unsur kecurangan, penghianatan, ingkar janji, Pedagang padi tidak paham tentang etika bisnis islam, etika bisnis islam sangat asing di telinga mereka, dikarenakan pedagang padi tersebut berpendidikan rendah, dan dalam sistem pembayaran dilakukan secara kekeluargaan dan kepercayaan tidak tuntutan hukum perdata ke pengadilan. Kemudian ada perilaku pedagang padi yang sesuai dengan etika bisnis diantaranya diakhir pembayaran mereka saling mendoakan antar pedagang dan petani, petani mengucapkan semoga mendapat untung yang banyak dan juga pedagang mengucapkan semoga uangnya bermanfaat dan dapat kebeli tanah sawah lagi.
\end{abstract}

Kata Kunci: Perilaku, Sosiologi ekonomi islam, etika bisnis islam

\section{PENDAHULUAN}

Kehidupan sehari-hari seorang manusia, tidak pernah luput dari yang namanya transaksi antar manusia yang satu dengan yang lainya. Karena manusia sebagai mahluk sosial. Pada diri manusia ada suatu kebutuhan yang harus dipenuhi. Manusia juga tidak bisa hidup sendiri tanpa adanya orang lain yang juga hidup di tengah-tengahnya. Manusia berinteraksi dengan sesamanya dalam kehidupan untuk menghasilkan pergaulan hidup dalam kelompok sosial. Karena itu dapat dikatakan bahwa interaksi sosial menurut Elly dan Setiadi dalam (Arifudin, 2020) adalah proses-proses sosial, yang merujuk pada hubungan-hubungan sosial yang dinamis.

Bisnis selalu memegang peranan yang sangat vital didalam kehidupan sosial dan ekonomi manusia sepanjang masa, sehingga kepentingan menurut Merza Gamal dalam (Fasa, 2020) bahwa bisnis akan mempengaruhi tingkah laku bagi semua tingkat individu, sosial regional, nasional dan internasional. Umat islam telah lama terlibat dalam dunia bisnis, yakni sejak empat belas abad yang silam. Fenomena tersebut bukanlah suatu hal yang aneh, karena islam menganjurkan umatnya untuk melakukan kegiatan bisnis. Rasulullah SAW sendiri terlibat didalam kegiatan bisnis selaku pedagang bersama istrinya Khadijah. 
Menurut (Arifudin, 2020) perkembangan dalam dunia usaha di Indonesia saat ini yang semakin cepat dan pesat berakibat juga pada perubahan budaya. Sehingga organisasi dituntut untuk mempunyai budaya yang membedakan dengan organisasi lain yang sejenis. Perubahan sudah merupakan fenomena global yang tidak bisa dibendung.

Al-qur'an memandang bisnis sebagai pekerjaan yang menguntungkan dan menyenangkan kitab suci umat islam ini dengan jelas mendorong para pedagang untuk melakukan sebuah perjalan jauh dan melakukan bisnis dengan para penduduk di negeri asing. Hal ini berarti bahwa perdagangan listas atau globalisasi bukan suatu yang aneh dalam Al-Qur'an.

Dalam konteks sosiologi ekonomi islam semua aktifitas harus mengacu pada al-Quran dan alHadist ataupun ijtihad para ulama begitu juga dalam hal bisnis maka harus mengacu pada hukumhukum dasar terebut didalam etika bisnis islam dikendalikan oleh halal dan haram baik cara memperolehnya ataupun cara pemanfaatanya. Islam melarang semua bentuk transaksi yang akan menimbulkan kesulitan dan masalah. Semua pihak terlibat dalam bisnis itu tidak dijelaskan dengan seksama yang akibatnya memungkinkan sebagian dari pihak yang terlibat bisa menarik keuntungan namun dengan merugikan pihak lain.

Al-Quran sebagai sumber nilai, telah memberikan batasan-batasan umum mengenai nilai-nilai prinsipil yang harus dijadikan acuan dalam berbisnis. Al-batil (falsu), Al-fasad (rusak), dan Al-zalim yang disebutkan dalam Al-Qurran dapat difungsikan sebagai landasan bagi prilaku yang bertentangan dengan prilaku yang dibolehkan Al-Quran dalam berbisnis.

Kasus yang terjadi antara pedagang padi dan petani harus berdasarkan nilai-nilai atau ajaran moral dalam Islam tidak bisa dipisahkan dari konsep tauhid, yang merupakan titik sentral dari ajaran Islam. Dalam bidang ekonomi, tahuid merupakan keyakinan bahwa Allah sebagai pemberi dan pengatur rizki bagi hamba-Nya. Pemilik sempurna dari harta yang dititipkan kepada umat manusia. Keyakinan ini menimbulkan paradigma baru bagi orang yang beriman bahwa kegiatan usaha harus disandarkan pada nilai-nilai yang telah ditetapkan dan keyakinan akan adanya pengawasan Allah.

Berdasarkan hal inilah peneliti tertarik untuk meneliti Perilaku Pegadang Padi ditinjau dari Sosiologi Ekonomi Islam dan Etika Bisnis Islam di Daerah Subang khususnya di Desa Karanghegar Kecamatan Pabuaran Kabupaten Subang Jawa Barat.

\section{KAJIAN PUSTAKA}

Menurut Al Bara dalam (Febrianty, 2020) mengemukakan bahwa pengertian perilaku pedagang tersusun dari dua kata, yaitu kata perilaku dan pedagang. Perilaku adalah suatu sifat yang ada dalam diri manusia. Perilaku manusia sederhananya di dorong oleh motif tertentu Dalam Kamus Besar Bahasa Indonesia (2001:671), perilaku adalah tanggapan atau reaksi individu yang terwujud dalam gerakan (sikap), tidak saja badan atau ucapan. Sedangkan pengertian pedagang secara etimologi menurut (Sujatmiko, 2014) adalah orang yang berdagang atau bisa disebut juga saudagar. Pedagang ialah orang yang melakukan perdagangan, memperjual belikan produk atau barang yang tidak diproduksi sendiri untuk memperoleh keuntungan. Pedagang adalah mereka yang melakukan perbuatan perniagaan sebagai pekerjaannya sehari-hari. Perbuatan perniagaan pada umumnya merupakan perbuatan pembelian barang untuk dijual lagi.

Sifat aktif-reseftif konsepsi tentang tindakan ekonomi yang melihat aktor sebagai entitas yang dikontrusikan secara sosial, dalam istilah keislamanya disebut 'amal al-iqtishady atau tadabir aliqtishadiyyat yakni 'amal (perbuatan, tindakan) yang mengandung makna atau bernuansa ekonomik atau bahan motif ekonomi. 'amal merupakan konsep sosiologis karena dilihat dalam kerangka hablun min al-nas (hubungan antara sesama manusia, interaksi sosial) didalam mana aktor mengaktualisasi nilai-nilai, motif atau niatnya. Dengan demikian menurut Muhamad Fachru Rozi dalam (Tanjung, 2020) tindakan ekonomi ('amal al-iqtishady) dalam perspektif sosiologi (yang sarat nilai, islami) 
merupan tindakan yang dilandasi oleh kesadaran yang bercorak ilahiyyat (keimanan) dan insaniyyat (manusiawi) sekaligus.

Menurut (Aziz, 2013) bahwa Etika bisnis Islam merupakan suatu proses dan upaya untuk mengetahui hal-hal yang benar dan yang salah yang selanjutnya tentu melanjutkan tentu melakukan hal yang benar berkenaan dengan produk, pelayanan perusahaan dengan pihak yang berkepentingan dengan tuntutan perusahaan. Mempelajari kualitas moral kebijaksanaan organisasi, konsep umum dan standart untuk perilaku moral dalam bisnis, berperilaku penuh tanggung jawaban dan bermoral. Artinya etika bisnis Islami merupakan suatu kebiasaan atau budaya moral yang berkaitan dengan kegiatan bisnis suatu perusahaan.

\section{METODE PENELITIAN}

Metode yang digunakan dalam penelitian ini adalah metode deskriptif kualitatif. Dalam penelitian terkait perilaku pedagang padi ditinjau dari sosiologi ekonomi islam dan etika bisnis islam, dilakukan berbagai persiapan sebelum penelitian yakni mengidentifikasi masalah/mencari permasalahan, merumuskan masalah, mengadakan studi pendahuluan, dan menentukan sampel penelitian. Fokus dalam penelitian terkait perilaku pedagang padi ditinjau dari sosiologi ekonomi islam dan etika bisnis islam ini memiliki dua tujuan yang penting, yakni menetapkan fokus untuk membatasi studi, dalam hal ini membatasi bidang inkuiri, misalnya, membatasi diri pada penggunaan teori yang sesuai dengan masalah yang diteliti, sedang teori yang tidak sesuai sedapat mungkin dihindari penggunaannya, dan menetapan focus penelitian berfungsi untuk memenuhi kriteria inkluisiinkluisi seperti perolehan data yang baru dilapangan.

Menurut (Moleong, 2007) bahwa fokus penelitian membantu peneliti dalam mengetahui dengan pasti data yang perlu dikumpulkan dan data yang tidak perlu dalam proses pengumpulan data. Sehingga, dengan langkah menetapkan fokus secara jelas dan valid, seorang peneliti dapat membuat keputusan yang tepat tentang data mana yang akan di kumpulkan dan mana yang tidak diperlukan.

Masalah yang terjadi dan fokus penelitian sangat terkait, oleh karena itu permasalahan penelitian dijadikan sebagai acuan di dalam fokus, walaupun fokus dapat berubah dan berkembang secara bebas berdasar pada fenomena-fenomena di lapangan sesuai dengan perkembangan permasalahan penelitian yang ditemukan dilapangan. Tempat penelitian adalah tempat peneliti dapat menangkap keadaan yang sebenarnya dari objek yang akan diteliti. Adapun lokasi penelitian adalah Desa Karanghegar Kecamatan Pabuaran Kabupaten Subang Provinsi Jawa Barat, penetapan lokasi penelitian ini dikarenakan Desa Karanghegar Kecamatan Pabuaran Kabupaten Subang Provinsi Jawa Barat ini memiliki masalah yang kompleks untuk diteliti.

\section{HASIL DAN PEMBAHASAN}

Hasil penelitian terkait perilaku pedagang padi ditinjau dari sosiologi ekonomi islam dan etika bisnis islam dilihat dari hasil observasi, wawancara dan dokumentasi. Berdasarkan hasil triangulasi yang dilakukan pada penelitian ini maka secara valid menghasilkan berbagai data-data yakni sebagai berikut :

\section{A. Perilaku Pedagang Padi ditinjau dari Sosiologi Ekonomi Islam}

1) Bersifat curang untuk meraup keuntungan besar

Pedagang untuk mencari keuntungan yang sebesar-besarnya pada saat transaksi yang sama telah merugikan pihak lain. Dalam konteks ini moral ekonomi tidak mampu menjadi pengendali tindakan ekonomi yang merugikan pihak lain yang terkait. Kecurangan dalam berbisnis dengan tujuan untuk meraup keuntungan sebesar-besarnya sebuah prinsip konvensional yang tidak mempedulikan prinsip syariah yaitu halal dan haram. praktik ini telah mewarnai perilaku ekonomi dalam berbagai bentuk seperti menghalalkan segala cara 
untuk mendapatkan keuntungan secara sepihak. Perspektif bisnis, prinsip ekonomi yang mewarnai setiap tindakan ekonomi yang bertujuan memperoleh keuntungan sebesar-besarnya dengan pengorbanan yang serendah-rendahnya telah menciptakan keserakahan yang terjadi secara masif dalam berbagai dimensi kehidupan bisnis saat ini.

Persoalan moral ekonomi selalu menjadi topik perbincangan yang semakin mengemuka akhir-akhir ini seiring dengan semakin banyaknya malpraktik dalam kegiatan ekonomi baik dalam kegiatan produksi maupun jasa termasuk banyaknya kasus kecurangan dalam kegiatan bisnis sehingga isu moral telah menjadi pusat perhatian ahli-ahli ekonomi syariah. Prinsip dasar ekonomi islam terkait dengan akidah, syariah dan akhlaq islam bagian integral dari islam sehingga tidak bisa dipisahkan dengan bagian islam yang lain, yaitu aqidah, syariah dah akhlaq. Karena itu setiap ekonomi islam adalah ibadah dalam rangka mengabdi kepada Allah SWT. setiap Nilai-nilai atau ajaran moral dalam Islam mengajarkan kepentingan bisnis yang tidak terpisahkan dari konsep Tauhid, yang merupakan titik sentral dari ajaran Islam. Dalam ajaran Islam bagi orang yang beriman harus ada keyakinan dan prinsip bahwa kegiatan usaha harus dilakukan berdasarkan pada nilai-nilai yang telah ditetapkan Allah karena semua kegiatan manusia ada dalam pengawasan Allah. Keyakinan adanya pengawasan Allah inilah yang akan mengkoreksi cara pandang, meluruskan sikap dan mengendalikan perilaku pengusaha dalam kegiatan bisnis yang pada akhirnya akan membentuk sikap mental, akhlak, dan etika para pelaku ekonomi.

Secara umum tindakan ekonomi bisa dipandang sebagai cerminan langsung dari moral ekonomi, yang menurut Evers pada kelompok pedagang merupakan cerminan kombinasi antara moral ekonomi dan kepentingan ekonomi. Moral ekonomi pedagang timbul ketika mereka menghadapi ethical dilemma dalam aktivitas jual beli yaitu antara mengutamakan kepentingan diri sendiri dan kepentingan orang lain. Kepentingan diri tanpa pertimbangan moral cenderung menimbulkan tindakan distributif atau asertif yaitu kepentingan keuntungan bagi diri sendiri.

2) Penghianatan dalam berbisnis

Perilaku penghianatan terhadap pelaku bisnis merupakan perilaku yang sembrono dan merugikan kepada patner bisnis yang berakibat merasa kapok dan tidak mau lagi dalam melakukan transaksi dan juga merugikan diri sendiri yaitu berbuat dosa yang menjadi catatan amal buruk kepada Tuhan-Nya. Ekonomi islam melihat inti masalah yang sama dalam menjelaskan konsep tindakan atau perilaku ekonomi merupakan prinsip rasionalis mengalami perluasan spectrum, yakni dengan melibatkan pertimbangan-pertimbangan syariah misalkan halal-haram, maslahah-mudharat dalam menenutukan seperangkat pilihan sejumlah referensi yang bersifat stabil. Dalam menentukan fungsi utilitasnyapun tidak mengabaikan aspek ruang waktu yang dirumuskan dalam tema kehidupan dunia (hayat ad-dunya, sekarang dan di sini) dan akhirat (hayat al-akhirat, kelak dan di sana). Prinsip rasional islam, menjadi asumsi dasar bagi perilaku ekonomi islam.

Konsep tindakan ekonomi sosiologi islam, bahwa dalam tradisi intelektual islam setiap pembahasan mengenai manusia ( dan perilakunya) selalu dilihat dalam konteks tiga realitas dasar yang saling berhubungan; Tuhan, manusia dan alam. Ketiga realitas dasar ini merupakan unitas (ketunggalan) yang didalamnya terdapat struktur-struktur hubungan yang sangat rumit dan komplek. Kompleksitas ditunjukan oleh sruktur hubungan yang senantiasa berubah ketika terdapat perubahan sudut pandang. Prinsip dasar hubungan ini, dalam arti teologi-dogmatisnya, bahwa tuhan adalah pencipta (khaliq) dan dua realitas lainya yaitu( mahluk). 
3) Ingkar janji dalam berbisnis

Permasalahn keuangan yang merupakan hasil transaksi dalam jual beli merupakan sesuatu yang sanagt penting, fenomena yang dialami pelaku bisnis dalam hal pembayaran yang tidak sesuai dengan kesepakan karena faktor kesengajaan dan tidak di tidak disengaja. Faktor kesengajaan bagi para pedagang merupakan tindakan penghiatan yang harusnya perjanjian ditepati tetapi perjanjian tersebut dihianati. Perilaku ingkar janji yang membuat hubungan moral kurang baik dalam hubungan bisnis yang merupakan hubungan hablun min al-nas (hubunhgan antar manusia) dan juga hablun min Allah (hubungan kepada Allah) merupan sebuah tindakan dosa kepada Allah. Dua jenis hubungan dalam setiap hubungan didalam dan diantara ketiga realitas dasar tersebut vertical dan horisontal.

Faktor ketidak sengajaan kepada objek bisnis karena banyak faktor dilapangan seperti modal yang tidak sebanding dengan permintaan pasar sehingga dengan modal seadanya barang yang dibeli dari objek bisnis menunggu dijual terlebih dahulu untuk membayarnya. Tindakan penundaan pembayaran terhadap petani membuat Sifat aktif-reseftif konsepsi tentang tindakan ekonomi yang melihat aktor sebagai entitas yang dikontrusikan secara sosial, dalam istilah keislamanya disebut 'amal al-iqtishady atau tadabir al-iqtishadiyyat yakni 'amal (perbuatan, tindakan) yang mengandung makna atau bernuansa ekonomik atau bahan motif ekonomi. 'amal merupakan konsep sosiologis karena dilihat dalam kerangka hablun min al-nas (hubungan antara sesama manusia, interaksi sosial) didalam mana aktor mengaktualisasi nilai-nilai, motif atau niatnya. Dengan demikian tindakan ekonomi('amal aliqtishady) dalam perspektif sosiologi (yang sarat nilai, islami) merupan tindakan yang dilandasi oleh kesadaran yang bercorak ilahiyyat (keimanan) dan insaniyyat (manusiawi) sekaligus.

\section{B. Perilaku Pedagang Padi Ditinjau Dari Etika Bisnis Islam}

1) Perilaku pedagang dalam menimbang padi

Perilaku Pedagang/pembeli padi dalam praktek menimbangan padi yang cenderung tidak memenuhi unsur keadilan dan sangat merugikan petani. Ketika padi sudah dipanen dan terlihat hamparan padi maka selanjutnya ada transaksi jual beli padi antara pedagang/pembeli padi dengan perantara makelar/calo kepada petani. Ketika sudah terjadi kesepakatan harga antara kedua belah pihak antara pedagang /pembeli padi dengan petani selanjutnya yaitu melakukan penimbangan padi. Dalam praktek penimbangan padi biasanya si Pedagang/pembeli padi dalam menimbang dengan timbangan gantung yang bobotnya $100 \mathrm{~kg}$. Menurut hasil wawancara terhadap pembeli padi dalam praktek menimbangan padi si pembeli/pedagang padi minta "hangat" dalam timbangannya. Hangat dalam timbangan yaitu posisi jarum tidak berada ditengah-tengah, melainkan posisi jarum timbangan tidak lurus, posisi jarum atas ke sebelah kiri dan jarum timbangan bawah bergeser kesebelah kanan, dikarenakan hitungan timbangan sudah bergeser kedepan. Berdasarkan data dari pembeli padai dalam artian bobot padi tersebut sudah hilang antara $\pm 0.5 \mathrm{~kg}$ sampai $1 \mathrm{~kg}$. Tentunya dengan cara penimbangan tersebut mengurangi bobot padi, yang terjadi adalah kerugian dipihak petani dan keuntungan dipihak pembeli/pedagang padi. Itu hanya dalam satu kali praktek timbangan, dikarenakan petani dalam penjualan padinya puluhan ton maka akan terjadi beberapakali timbangan, tentunya akan terjadi kehilangan tonase padi yang lebih besar. Dengan terjadinya beberapa kali penimbangan maka tidak memenuhi unsur keadilan dalam menimbang, berat sebelah, yang dirugikan adalah petani dan keuntungan di pihak pedagang/pembeli padi. 
Menurut etika dalam berbisnis cara penimbangan harus seimbang, memenuhi unsur keadilan, tidak ada pihak yang dirugikan kedua belah pihak.

a) Curang Dalam Timbangan Dan Takaran

Perilaku pedagang dalam menimbang padi apabila menerima takaran dari orang lain mereka minta dipenuhi. Dan apabila mereka menakar atau menimbang untuk orang lain, mereka mengurangi sesuai dengan Firman Allah yang artinya "Kecelakaan besarlah bagi orang-orang yang curang. (Yaitu) orang-orang yang apabila menerima takaran dari orang lain, mereka minta dipenuhi. Dan apabila mereka menakar atau menimbang untuk orang lain, mereka mengurangi. Tidakkah orang-orang itu yakin bahwa sesungguhnya mereka akan dibangkitkan. Pada suatu hari yang besar. (Yaitu) hari (ketika) manusia berdiri menghadap Rabb semesta alam. Allâh Azza wa Jalla langsung menafsirkan hakekat muthaffifîn (yang melakukan kecurangan. Praktek kecurangan mereka seperti yang diterangkan Allâh Azza wa Jalla, jika orang lain menimbangkan atau menakar bagi mereka sendiri, maka mereka menuntut takaran dan timbangan yang penuh dan sekaligus meminta tambahan. Mereka meminta hak mereka dipenuhi dengan sebaik-baiknya, bahkan minta dilebihkan. Namun apabila mereka yang menakar atau menimbang untuk orang lain, mereka mengurangi kadarnya sedikit, baik dengan cara menggunakan alat takar dan timbangan yang sudah direkayasa, atau dengan tidak memenuhi takaran dan timbangannya, atau dengan cara-cara curang lainnya. Mereka tidak suka orang lain mendapatkan perlakuan yang sama dengan perlakuan untuk dirinya dengan dipenuhi timbangan dan takaran bila membeli

b) Bahaya mengurangi timbangan.

Kecurangan tersebut jelas merupakan satu bentuk praktek sariqah (pencurian) terhadap milik orang lain dan tidak mau bersikap adil dengan sesama. Dengan demikian, bila mengambil milik orang lain melalui takaran dan timbangan yang curang walaupun sedikit saja berakibat ancaman doa kecelakaan. Dan tentu ancaman akan lebih besar bagi siapa saja yang merampas harta dan kekayaan orang lain dalam jumlah yang lebih banyak. Syaikh 'Abdurrahmân as-Sa'di rahimahullah dalam tafsirnya mengatakan, "Jika demikian ancaman bagi orang-orang yang mengurangi takaran dan timbangan orang lain, maka orang yang mengambil kekayaan orang lain dengan paksa dan mencurinya, ia lebih pantas terkena ancaman ini daripada muthaffifîn. Tentang bahaya kecurangan ini terhadap Petani, Syaikh 'Athiyyah Sâlim rahimahullah mengatakan, "Diawalinya pembukaan surat ini dengan doa kecelakaan bagi para pelaku tindakan curang dalam takaran dan timbangan itu menandakan betapa bahayanya perilaku buruk ini. Dan memang betul, hal itu merupakan perbuatan berbahaya. Karena timbangan dan takaran menjadi tumpuan roda perekonomian dunia dan asas dalam transaksi. Jika ada kecurangan di dalamnya, maka akan menimbulkan khalal (kekisruhan) dalam perekonomian, dan pada gilirannya akan mengakibatkan ikhtilâl (kegoncangan) hubungan transaksi. Ini salah satu bentuk kerusakan yang besar"

c) Perintah Menyempurnakan Timbangan.

Islam dengan kesempurnaan, kemuliaan dan keluhuran ajarannya, memerintahkan umatnya untuk menjalin muamalah dengan sesama atas dasar keadilan dan keridhaan. Di antaranya, dengan menyempurnakan timbangan dan takaran. Allâh Azza wa Jalla berfirman yang artinya "Dan tegakkanlah timbangan itu dengan adil dan janganlah kamu mengurangi neraca itu". Orang yang menyalahi ketentuan yang adil ini berarti telah menjerumuskan dirinya sendiri dalam ancaman kebinasaan. Dan sampai sekarang, praktek ini masih menjadi karakter sebagian orang yang melakukan jual-beli, baik 
pedagang maupun pembeli. Dengan mendesak, pembeli meminta takaran dan timbangan dipenuhi, dan ditambahi. Sementara sebagian pedagang melakukan hal sebaliknya, melakukan segala tipu muslihat untuk mengurangi takaran dan timbangan guna meraup keuntungan lebih dari kecurangannya ini.

2) Perilaku pedagang padi hianat dalam mengembalikan pinjaman karung karung kepada petani

Fenomena perilaku pedagang padi kehabisan karung biasanya karung petani yang dibawa ke penggilingan padi dan akan dikembalikan dengan waktu tertentu tetapi ketika dikembalikan karung tersebut tidak sesuai dengan karung yang dibawa yaitu mendapatkan karung yang lebih jelek dan sobek dengan alasan tertukar di gudang dengan yang lainya, tentunya ini sangat merugikan petani yang asalnya karung bagus dengan harga satuan \pm Rp. 3 Ribu dan apabila dalam jumlah banyak maka kerugian yang besar dalam jumlah jutaan rupiah.

a. bersifat Jujur dalam berbisnis

Kejujuran merupakan ajaran Islam yang mulia. Hal ini berlaku dalam segala bentuk muamalah, lebih-lebih dalam jual beli karena di dalamnya sering terjadi sengketa. Jual beli online adalah di antara jual beli yang ditekankan adanya sifat kejujuran. Kejujuran inilah yang nantinya mendatangkan keberkahan.

b. Penekanan Sifat Jujur bagi Pelaku Bisnis

Terkhusus lagi, terdapat perintah khusus untuk berlaku jujur bagi para pelaku bisnis karena memang kebiasaan mereka adalah melakukan penipuan dan menempuh segala cara demi melariskan barang dagangan. Dari Rifa'ah, ia mengatakan bahwa ia pernah keluar bersama Nabi shallallahu 'alaihi wa sallam ke tanah lapang dan melihat manusia sedang melakukan transaksi jual beli. Beliau lalu menyeru, "Wahai para pedagang!" Orang-orang pun memperhatikan seruan Rasulullah shallallahu 'alaihi wa sallam sambil menengadahkan leher dan pandangan mereka pada beliau. Lantas Nabi shallallahu 'alaihi wa sallam bersabda yang artinya "Telah menceritakan kepada kami [Abu Salamah Yahya bin Khalaf] telah menceritakan kepada kami [Bisyr bin Al Mufadhdhal] dari [Abdullah bin Utsman bin Khutsaim] dari [Isma'il bin Ubaid bin Rifa'ah] dari [ayahnya] dari [kakeknya] bahwa ia pernah keluar bersama Nabi shallallahu 'alaihi wasallam menuju tempat shalat, lalu beliau melihat orang-orang melakukan transaksi jual beli, beliau pun bersabda: "Wahai para pedagang." Lalu mereka menyambut seruan Rasulullah shallallahu 'alaihi wasallam dan mengangkat leher dan pandangan mereka kepada beliau, lalu beliau bersabda: "Sesungguhnya para pedagang akan dibangkitkan pada hari kiamat sebagai orang-orang yang berdosa kecuali yang bertakwa kepada Allah, berbuat baik serta jujur." Abu Isa berkata; Hadits ini hasan shahih. Isma'il bin Ubaid bin Rifa'ah dipanggil juga dengan Isma'il bin Ubaidullah bin Rifa'ah."

c. Keutamaan berbuat jujur dalam Bisnis

Dari sahabat Hakim bin Hizam, Nabi shallallahu 'alaihi wa sallam bersabda yang artinya : "Telah menceritakan kepada kami [Badal bin Al Muhabbar] telah menceritakan kepada kami [Syu'bah] dari [Qatadah] berkata, aku mendengar [Abu Al Khalil] menceritakan dari ['Abdullah bin Al Harits] dari [Hakim bin Hizam radliallahu 'anhu] dari Nabi shallallahu 'alaihi wasallam bersabda: "Dua orang yang melakukan jual beli boleh melakukan khiyar (pilihan untuk melangsungkan atau membatalkan jual beli) selama keduanya belum berpisah", Atau sabda Beliau: "hingga keduanya berpisah. Jika keduanya jujur dan menampakkan cacat dagangannya maka keduanya diberkahi dalam jual belinya dan bila menyembunyikan cacat dan berdusta maka akan dimusnahkan keberkahan jual belinya." Di antara keberkahan sikap jujur ini akan memudahkan kita mendapatkan berbagai jalan keluar dan kelapangan. 
3) Ingkar janji dalam berbisnis masalah Pembayaran

Didalam pembayaran padi yang sudah disepakati antara pedagang/pembeli dan petani yaitu dengan DP (down payment) dan biasanya pembayaran lunas setelah beberapa hari kemudian sesui kesepakatan antara pedagang padi dengan petani. Karena jarang sekali seorang pedagang/pembeli padi melakukan pembayaran secara kontan dengan alasan modal tidak cukup dan permintaan pasar banyak untuk DP (down payment) di petani lainya, oleh karena itu didalam pembayaran sering meleset dengan perjanjian waktu yang telah ditentukan, terkadang pembayaran yang dilakukan pedagang/pembeli padi setelah padinya digiling jadi beras dan dijual di pasar induk.

Dengan kejadian tersebut maka sering terjadi kelambatan dalam pembayaran, kalaupun seorang petani ingin mendapatkan pembayaran secara kontan yaitu dijual dengan jual beli padi secara borongan karena biasanya satu hari sebelum padi dipanen yaitu dibayar kontan oleh pemboorong padi. Pembayaran yang tidak sesuai dengan perjanjian yang telah disepakati. Janji memang ringan diucapkan namun berat untuk ditunaikan. Betapa banyak orangtua yang mudah mengobral janji kepada anaknya tapi tak pernah menunaikannya. Betapa banyak orang yang dengan entengnya berjanji untuk bertemu namun tak pernah menepatinya. Dan betapa banyak pula orang yang berhutang namun menyelisihi janjinya. Bahkan meminta udzur pun tidak. Padahal, Rasulullah telah banyak memberikan teladan dalam hal ini termasuk larangan keras menciderai janji dengan orang-orang kafir. Manusia dalam hidup ini pasti ada keterikatan dan pergaulan dengan orang lain. Maka setiap kali seorang itu mulia dalam hubungannya dengan manusia dan terpercaya dalam pergaulannya bersama mereka, maka akan menjadi tinggi kedudukannya dan akan meraih kebahagiaan dunia dan akhirat. Sementara seseorang tidak akan bisa meraih predikat orang yang baik dan mulia pergaulannya, kecuali jika ia menghiasi dirinya dengan akhlak-akhlak yang terpuji. Dan di antara akhlak terpuji yang terdepan adalah menepati janji.

\section{KESIMPULAN}

Berdasarkan hasil penelitian terkait perilaku pedagang padi ditinjau dari sosiologi ekonomi islam dan etika bisnis islam bahwa dapat disimpulkan yakni sebagai berikut :

a) Berdasarkan data yang ditemukan bahwa perilaku pedagang padi ditinjau dari sosiologi Ekonomi Islam unsur kecurangan untuk meraup keuntungan yang sebesar-besarnya dengan alasan mereka tidak mau rugi.

b) Perilaku pedagang padi ditinjau dari Etika Bisnis Islam : 1) Perilaku pedagang padi dalam transaksi tidak sesui dengan etika bisnis ada unsur kecurangan, 2) Pedagang padi tidak paham tentang etika bisnis islam, etika bisnis islam sangat asing di telinga mereka, dikarenakan pedagang padi tidak menempuh pendidikan tinggi, dan 3) Dalam sistem pembayaran dilakukan secara kekeluargaan dan kepercayaan tidak tuntutan hukum perdata ke pengadilan

c) Ada perilaku pedagang padi yang sesuai dengan etika bisnis diantaranya diakhir pembayaran mereka saling mendoakan antar pedagang dan petani, petani mengucapkan "semoga mendapat untung yang banyak" dan juga pedagang mengucapkan "semoga uangnya bermanfaat dan dapat kebeli tanah sawah lagi".

Adapun saran berdasarkan hasil penelitian diatas terkait perilaku pedagang padi ditinjau dari sosiologi ekonomi islam dan etika bisnis islam yakni sebagai berikut :

a) Hendaknya pedagang padi sebagai pelaku bisnis menyadari bahwa dalam praktek menimbang padi harus seimbang tidak ada pihak yang dirugikan sebagai wujud penerapan etika bisnis islam. 
b) Sebaiknya pedagang padi memperhatikan ketelitian tentang meyimpan barang yang didapat dari meminjam harus benar-benar diperhatikan suapaya barang yang dipinjam tidak hilang kalaupun barannya hilang maka harus diganti dengan kwalitas yang lebih bagus.

c) Sebaiknya apabila ada keterlambatan pembayaran pedagang padi memberi tahu kepada pihak terkait dan berusaha keras untuk membayar tepat waktu.

d) Sebaiknya seluruh pedagang padi yang ada di Desa Karanghegar memahami dan menerapkan Etika Bisnis Islam seperti yang telah dilakukan oleh Rasulullah SAW dalam menjalankan roda bisnis.

e) Pemerintahan daerah dan pihak terkait dalam hal ini memberikan penyuluhan kepada pedagang padi untuk memberikan pendalaman agama supaya dalam melakukan bisnis tidak keluar jalur yang berseberangan dengan syariat untuk menerapkan etika bisnis islam dalam berbisnis.

\section{REFERENSI}

Arifudin, O. (2020). Analisis Budaya Organisasi Dan Komitmen Organisasi Karyawan Bank Swasta Nasional Di Kota Bandung. Jurnal Ilmiah MEA (Manajemen, Ekonomi, Dan Akuntansi), 4(2), 73-87.

Arifudin, O. (2020). Psikologi Pendidikan (Tinjauan Teori Dan Praktis). Bandung: Widina Bhakti Persada.

Aziz, A. (2013). Etika Bisnis Perspektif Islam. Bandung : Alfabeta.

Fasa, I. (2020). Eksistensi Bisnis Islami Di Era Revolusi Industri 4.0. Bandung: Widina Bhakti Persada.

Kamus Besar Bahasa Indonesia. (2001). Jakarta : Balai Pustaka.

Moleong. (2007). Metodologi Penelitian Kualitatif. Bandung: PT. Remaja Rosdakarya.

Sujatmiko. (2014). Kamus IPS. Surakarta: Aksara Sinergi media.

Tanjung, R. (2020). Manajemen Pemasaran Pendidikan. Bandung: Widina Bhakti Persada. 